\title{
Improving communication between citizens and authorities in the process of providing municipal services in urban and rural areas
}

\author{
Natalya Chevtaeva ${ }^{1}$,Elena Kachanova ${ }^{1}$, Aleksey Ruchkin ${ }^{2, *}$, and Viktor Kukhar ${ }^{2}$ \\ ${ }^{1}$ Russian Presidential Academy of National Economy and Public Administration, 8 March street, 66, \\ 620144 Yekaterinburg, Russia \\ ${ }^{2}$ Ural State Agrarian University, ul. Karl Liebknecht, 42, 620075 Yekaterinburg, Russia
}

\begin{abstract}
The article analyzes the level of satisfaction with the provision of state and municipal services in Sverdlovsk region. Based on the results of a sociological study, the preferences of the population in the way of providing services and receiving information, as well as the level of satisfaction with the quality of services provided, are considered. The problem of high-quality provision of state and municipal services by employees of multi-functional centers is considered. Special attention is paid to the areas of improving the process of providing services to the population and improving the level of service.
\end{abstract}

\section{Introduction}

E-government and the concept of the "service state" as a new system of organizing the activities of state authorities and local self-government is one of the main points of implementation of modern administrative reform in Russian Federation, which provides a qualitatively new level of interaction in the implementation of functions based on the use of information and communication technologies. For the effective implementation of this concept, it is necessary to unite the elements of the e-government system both at the federal level and at the level of the subjects and their constituent municipalities. The problem lies in the absence of not only a single regulatory framework, but also a single set of implementation tools for the formation of e-government at the federal level and in individual subjects of Russian Federation. The consequence of this problem is the low efficiency of the system functioning at the level of subjects, which does not allow achieving the targets of state programs related to the informatization of society. For example, by the beginning of 2018, satisfaction with the quality of services reached $86 \%$, and waiting time in the queue - 19 minutes, while the strategic targets for 2018 are $90 \%$ and 15 minutes, respectively.

The effectiveness of the e-government system and the quality of the provision of state and municipal services also negatively affect the demand for services provided in electronic

\footnotetext{
*Corresponding author: alexeyruchkin87@gmail.com
} 
form from the population and organizations that prefer to receive them through personal treatment, which is confirmed by the results of empirical studies.

The e-government system that is being formed in Russian Federation is considered in the works of Babaev E.A.O. [1] and Balyukov A.S. [2] (analysis of the relevance of creating e-government), Bulgatova E.S., Dyrheev A.V. [3] and Dianova E.M. [4] (egovernment as a mechanism for influencing transaction costs in the public sector), Nyakina E.S. [5] (research of prospects for the development of e-government), Sultanov K.V. [6] (features of interaction between government and society through the e-government system) and others. Questions of development of quality of rendering of state and municipal services are considered by Chevtaeva N.G., Fedorova E.O. [7], Sergeeva T.A. [8], Mokronosov A.G. [9] and other researchers, who point to the need to improve the quality of services, improve the standards of public service.

\section{Method}

The conclusions are based on the results of a sociological survey conducted by the authors in 2018 among the population of large and small cities of the Sverdlovsk region using a questionnaire survey. The total number of respondents is 3,000. The survey was conducted in different types of cities in the Sverdlovsk region: in a city with a population of more than a million people (in Yekaterinburg-1,100 respondents); in a large city (in Nizhny Tagil 400 respondents) and a large city (in Kamensk-Uralsky-360 respondents); in medium sized cities (in Serov-300, Berezovsky-180, Verkhnyaya Pyshma-200 respondents), as well as in small cities (in Irbit and Irbit district 180, Aramil - 80, Kachkanar - 140, Kirovograd 60 respondents).

The assessment of the organization of the service delivery process was based on the results of an expert survey of employees of multifunctional centers (MFC) - 15 experts.

The purpose of the study was to find out how to establish communication between the authorities and the population of different types of cities in the process of providing municipal services: channels for informing about the procedure, methods and organization of receiving services, the regulatory role of assessing the quality of municipal services to improve the organization of service provision. The obtained conclusions allowed us to identify ways to optimize the communication of the service delivery process, taking into account the patterns of behavior of service consumers in different types of cities.

\section{Study detail and result}

The respondents ' answers to the question about the level of awareness about the procedure for providing services are divided into groups, depending on the type of city in which the respondents live (Table 1).

Table 1. The degree of awareness of the population of different types of cities about the procedure for providing municipal services (percentage of respondents)

\begin{tabular}{|l|c|c|c|c|}
\hline \multicolumn{1}{|c|}{ Answer options } & $\begin{array}{c}\text { City with a } \\
\text { population of over } \\
\text { a million people }\end{array}$ & $\begin{array}{c}\text { Large and } \\
\text { large city }\end{array}$ & $\begin{array}{c}\text { Medium } \\
\text { city }\end{array}$ & $\begin{array}{c}\text { Small } \\
\text { city }\end{array}$ \\
\hline Fully informed & 5,6 & 6,8 & 10,6 & 19,6 \\
\hline More informed than not & 36,8 & 30,3 & 29,2 & 44,8 \\
\hline Rather not informed & 35 & 32 & 28,1 & 24,4 \\
\hline Not informed & 8,3 & 9 & 16,4 & 6,4 \\
\hline $\begin{array}{l}\text { I find it difficult to } \\
\text { answer }\end{array}$ & 8,5 & 14,3 & 13, & 2,4 \\
\hline
\end{tabular}




\begin{tabular}{|l|l|l|l|l|}
\hline No response & & 7,8 & 2,8 & 2,4 \\
\hline Total & & & & 100 \\
\hline
\end{tabular}

Source: compiled by the authors

Adding up the positive answers "fully informed" and "more informed than not", we get a picture of a well-informed population of different types of cities. It would seem logical to assume that large cities provide great opportunities for information communication. Contrary to expectations, we observe that residents of small cities are the most informed (64.4\% versus $42.4 \%$ of residents of cities with a population of more than a million people; $37.1 \%$ of large and $39.8 \%$ of medium-sized cities).

How is this advantage achieved? What sources of information are the most popular among residents of different types of cities? (Table 2)

Table 2. Sources of information on the procedure for providing municipal services (percentage of respondents)

\begin{tabular}{|l|c|c|c|c|}
\hline \multicolumn{1}{|c|}{ Answer options } & $\begin{array}{c}\text { City with a } \\
\text { population of } \\
\text { over a million } \\
\text { people }\end{array}$ & $\begin{array}{c}\text { Large and } \\
\text { large city }\end{array}$ & $\begin{array}{c}\text { Medium } \\
\text { city }\end{array}$ & Small city \\
\hline $\begin{array}{l}\text { Information stands in the lobby of } \\
\text { government agencies, multifunctional } \\
\text { centers }\end{array}$ & 14,4 & 16,3 & 21,9 & 26,8 \\
\hline Municipal newspapers, magazines & 20,3 & 25,3 & 22,2 & 22,8 \\
\hline Local Radio & 13,8 & 16,5 & 11,9 & 18,4 \\
\hline Local television & 32,5 & 35,8 & 37,2 & 16,4 \\
\hline $\begin{array}{l}\text { Web pages on the official website of } \\
\text { municipal authority }\end{array}$ & 28,9 & 22 & 19,7 & 22,4 \\
\hline $\begin{array}{l}\text { Unified portal of state and municipal } \\
\text { services }\end{array}$ & 30,6 & 25 & 15,3 & 19,6 \\
\hline $\begin{array}{l}\text { Consultation during the personal } \\
\text { reception of citizens }\end{array}$ & 11,1 & 9,8 & 13,3 & 19,6 \\
\hline Telephone consultation & 9,5 & 6 & 8,3 & 3,2 \\
\hline $\begin{array}{l}\text { Other (During training, Online forums, } \\
\text { From friends and acquaintances, } \\
\text { Directly from documents) }\end{array}$ & 3,6 & 5 & 5 & 0,8 \\
\hline
\end{tabular}

Source: compiled by the authors

The analysis of the respondents ' answers to the question "In what form did you apply to local governments for municipal services?" shows the following picture (Table 3 ).

Table 3. The form in which the population of different types of cities prefers to receive municipal services (percentage of respondents)

\begin{tabular}{|l|c|c|c|c|}
\hline \multicolumn{1}{|c|}{ Form of service provision } & $\begin{array}{c}\text { City with a } \\
\text { population of over } \\
\text { a million people }\end{array}$ & $\begin{array}{c}\text { Large and } \\
\text { large city }\end{array}$ & $\begin{array}{c}\text { Medium } \\
\text { city }\end{array}$ & $\begin{array}{c}\text { Small } \\
\text { city }\end{array}$ \\
\hline $\begin{array}{l}\text { Personally to the reception offices of } \\
\text { local self-government authorities }\end{array}$ & 24,3 & 21,5 & 27,2 & 48 \\
\hline Through multifunctional centers & 16,7 & 24,8 & 18,6 & 21,6 \\
\hline In electronic form via the Internet & 12,3 & 13,5 & 13,9 & 8 \\
\hline No response & 44,9 & 37 & 35,6 & 16,8 \\
\hline Other & 1,2 & 2,8 & 3,6 & 5,6 \\
\hline Total & 100 & 100 & 100 & 100 \\
\hline
\end{tabular}

Source: compiled by the authors 


\section{Discussion}

Thus, the results of the study show that citizens prefer electronic form when searching for information about electronic services. The process of direct receipt of services still remains the prerogative of personal contact between a citizen and an employee (an employee of a multifunctional center or an official). The popularity of personal appeals to the authorities can obviously be explained by the high level of public complaints about the professionalism of the staff of the multifunctional center - "illiterate consultations on the documents provided".

An expert survey of employees of the multifunctional center allows you to see the organizational problems of the service provision process: "one employee of the MFC has a large number of different types of municipal services, the employee must know a lot of regulations for providing services in a variety of areas". It is necessary, according to the employees of the multifunctional center, to introduce specialization, when one employee provides services in a certain area, which will allow him to carefully study the regulations, know the required package of documents well, and, consequently, give citizens competent advice". Another reason for the mistakes of employees, the low qualification of the staff of the multifunctional center is, according to experts, "the weak motivation of employees to improve their professionalism. "The low level of wages leads to a high turnover of employees of the multifunctional center, which, of course, also affects the quality of services provided to the population".

\section{References}

1. E. A. O. Babaev, Managerial consulting, 8(116), 137 (2018)

2. Yu. S. Bulgatov, A.V. Dyrheev, Bulletin of the Buryat State University. Economics and Management, 1, 8 (2018)

3. A. S. Balyukov, Bulletin of the South Ural State University. Series: Computer technologies, control, radio electronics, 14(3), 78 (2014)

4. E. M. Dianova, Information Society, 4, 34 (2012)

5. E. S. Nyakina, E. A. Pogodina, Electronic bulletin, 31 (2012)

6. K. V. Sultanov, Bulletin of the Russian State Pedagogical University named after A.I. Herzen, 104, 66 (2009)

7. N. G. Chevtaeva, N. G. Fedorova, Monitoring of public opinion: economic and social changes, 5(123), 98 (2014)

8. N. G. Chevtaeva, A.V. Ruchkin, T. A. Sergeeva, Management issues, 2(45), 13 (2017)

9. A. G. Mokronosov, E. S. Ogorodnikova, A. E. Plakhin, Agrarian Bulletin of the Urals, 07(198), 85 (2020) 